\title{
In-vitro antibacterial, antifungal, antioxidant and functional properties of Bacillus amyloliquefaciens
}

\author{
Shine Kadaikunnan ${ }^{1}$, Thankappan Sarasam Rejiniemon ${ }^{2 *}$, Jamal M Khaled ${ }^{1}$, Naiyf S Alharbi ${ }^{1}$ and Ramzi Mothana ${ }^{3}$
}

\begin{abstract}
Background: Food born pathogenic bacteria and filamentous fungi are able to grow on most foods, including natural foods, processed foods, and fermented foods and create considerable economic loss. The aim of this study was to determine the antibacterial, antifungal, antioxidant and functional properties of Bacillus amyloliquefaciens recovered from silage.

Methods: Minimum Inhibitory Concentration (MIC) of the compounds was assessed by using broth micro dilution method. The 1,1-diphenyl-2-picrylhydrazyl (DPPH)-radical scavenging and hydroxyl radical-scavenging abilities were measured to evaluate antioxidant activity of the strain.

Results: Primary antimicrobial compound production screening revealed that B. amyloliquefaciens exhibited significant activity against all the tested bacteria and fungi compared to other strains. The $16 \mathrm{~S}$ rRNA and gyrase A gene sequence analysis determined using molecular biological tools confirmed that the strain was 99\% similarity towards B. amyloliquefaciens. The Minimum Inhibitory Concentration (MIC) of ethyl acetate extract against Bacillus subtilis, Enterococcus cloacae and Staphylococcus aureus were $25.0 \mu \mathrm{g} \mathrm{ml}^{-1}$, and S, epidermidis were $12.5 \mathrm{\mu g} \mathrm{ml}^{-1}$, respectively. Filamentous fungi Aspergillus clavatus, A. fumigates, A. niger and Gibberella moniliformis showed $25 \mathrm{\mu g} \mathrm{ml}^{-1}$. VJ-1 was able to survive the gastrointestinal conditions simulating the stomach and duodenum passage with the highest percentage of hydrophobicity. In addition, its resistance to hydrogen peroxide and highest hydroxyl radical and 2, 2-diphenyl-1-picrylhydrazyl (DPPH) scavenging activities, with inhibition rates of 56.84\% and 67.12\% respectively, were its advantage. An antimicrobial susceptibility pattern was an intrinsic feature of this strain, and thus, consumption does not represent a health risk to humans.
\end{abstract}

Conclusion: Bacillus amyloliquefaciens might be a promising candidate for new pharmaceutical agents and probiotics.

Keywords: Bacillus amyloliquefaciens, Antimicrobial activity, Probiotics, Antioxidant activities

\section{Introduction}

Antimicrobial metabolites are widespread produced among bacteria of the genus Streptomyces and Bacillus [1]. In particular, Bacillus strains are ubiquitous in the environment; they have been isolated worldwide from soil, ocean, and organic matter respectively. Members of the Bacillus species are good sources of bioactive compounds, notably antibiotics, therapeutic proteins, enzyme inhibitors and pharmacologically active agents [2]. They produce a large number of antimicrobial metabolites and bio-peptides with different chemical structures

\footnotetext{
* Correspondence: rejinie@gmail.com

2Department of Botany and Biotechnology, AJ College of Science and

Technology, Thonnakal, Trivandrum, India

Full list of author information is available at the end of the article
}

and diversity, such as bacteriocins, bacteriocin-like substances and lipopeptides [3]. Although most of these substances are active against Gram-positive bacteria, some of them have a wide range of bio-activity towards Gram-negative bacteria and filamentous fungi [4]. Among antifungal compounds, lipopeptides identified to play a major role in disease suppression [5]. Different types of lipopeptides are produced by several B. subtilis and B. amyloliquefaciens strains. However; few lipopeptides such as surfactin, iturin and fengycin were recovered from Bacillus species and characterized [6-9]. Although a number of studies have been carried out on isolation and characterization of antimicrobial metabolite producing Bacillus from different origin, few assessments 
of their performance in anti-fungal studies have been reported. The objective of the present study was

- Isolation of Bacillus amyloliquefaciens VJ-1 from silage and molecular level identification by $16 \mathrm{~S}$ rRNA and gyrase A (gyrA) gene sequencing

- Extraction of antimicrobial metabolites

- Evaluation of in vitro antibacterial and antifungal activities

- Evaluation of in vitro probiotic and antioxidant properties

\section{Materials and methods}

\section{Chemicals and reagents}

Culture media and antibiotics were purchased from Himedia, India. Dimethyl sulfoxide (DMSO) and 2, 2diphenyl-1-picrylhydrazyl (DPPH) were obtained from Sigma-Aldrich. The genomic DNA isolation kit and pGEM-T vector were purchased from Promega (Madison, WI, USA).

\section{Isolation of Bacillus strains}

The silage sample was used for the isolation of the new Bacillus strains. Briefly, an aliquot of $1 \mathrm{~g}$ of soil (sludge) sample was transferred into $100 \mathrm{ml}$ of Luria-Bertani (LB, Himedia, Mumbai) medium (10 $\mathrm{g} \mathrm{l}^{-1}$, casein peptone; $5 \mathrm{~g} \mathrm{l}^{-1}$, yeast extract and $5 \mathrm{gl}^{-1}, \mathrm{NaCl} ; \mathrm{pH} \mathrm{7.0)}$ and incubated aerobically at $37^{\circ} \mathrm{C}$ on an orbital shaker at $150 \mathrm{rpm}$ for $24 \mathrm{~h}$. After incubation the medium was serially diluted with saline $(0.85 \% \mathrm{NaCl})$ and plated on $\mathrm{LB}$ agar. The plates were incubated at $37^{\circ} \mathrm{C}$ and observed after $24 \mathrm{~h}$. Well isolated single colonies were selectively marked and propagated twice to check the purity and stored at $-80^{\circ} \mathrm{C}$ with $20 \%$ sterile glycerol for further investigation and propagated twice in the same medium at $37^{\circ} \mathrm{C}$ before use. Antimicrobial activity of Bacillus strains were checked by growing the cells on Modified Nutrient Glucose Agar MNGA (10 $\mathrm{g} \mathrm{l}^{-1}$, glucose; $5 \mathrm{~g} \mathrm{l}^{-1}$, peptone; $3 \mathrm{~g} \mathrm{l}^{-1}$, beef extract; $3 \mathrm{~g} \mathrm{l}^{-1}$, dry yeast; $3 \mathrm{~g} \mathrm{l}^{-1}, \mathrm{NaCl}$ and $3 \mathrm{~g} \mathrm{l}^{-1}, \mathrm{CaCO}_{3}$ ) plates by single streak in the center [1]. Strain VJ-1, with very good antagonistic activity, was selected for further studies.

\section{Identification of Bacillus sp. VJ-1 Biochemical tests}

The morphological properties were examined by light microscope. Biochemical and physiological properties of the isolate was analyzed using routine methods. API $50 \mathrm{CHB}$ test kit was used to characterize phenotypically. The API test strips were prepared according to the instructions of the kit supplier and scored after incubation for $24 \mathrm{~h}$ at $37^{\circ} \mathrm{C}$.
Antibiotic sensitivity and resistance pattern of Bacillus sp. VJ-1

Antibiotic sensitivity and resistance of Bacillus sp. VJ-1 was determined by disc diffusion method Arasu et al. [1]. Briefly, cells were prepared by growing in Muller Hinton (MH) medium (beef extract $2 \mathrm{~g} \mathrm{l}^{-1}$, casein acid hydrolysate $17.5 \mathrm{~g} \mathrm{l}^{-1}$, starch $1.5 \mathrm{~g} \mathrm{l}^{-1}$, agar $17 \mathrm{~g} \mathrm{l}^{-1}$ ) for $17 \mathrm{~h}$ at $37^{\circ} \mathrm{C}$. Petri plates were prepared with $25 \mathrm{ml}$ of sterile $\mathrm{MH}$ medium (Himedia). The test cultures $(100 \mu \mathrm{l})$ of suspension containing $10^{8} \mathrm{CFU} \mathrm{m}{ }^{-1}$ bacteria) were swabbed on the top of the solid media and allowed to dry for $10 \mathrm{~min}$. Different antibiotics loaded discs were placed on the surface of the medium and left for $30 \mathrm{~min}$ at room temperature for the diffusion of the antibiotics. Further, the plates were incubated for $17 \mathrm{~h}$ at $37^{\circ} \mathrm{C}$. After incubation, Bacillus sp. VJ-1was classified as sensitive or resistant to an antibiotic according to the diameter of inhibition zone given in standard antibiotic disc chart.

\section{Scanning electron microscopy (SEM)}

Twenty four h grown cells of Bacillus sp. VJ-1 were used for the SEM observations. The slats free cells were fixed by using glutaraldehyde $(2.0 \%)$ and paraformaldehyde $(2.0 \%)$ containing $0.1 \mathrm{M}$ sodium cacodylate buffer ( $\mathrm{pH}$ 7.2). After that the cells were coated with poly-L-lysine $(75 \mathrm{mM})$. After dehydration cells were finally coated with gold at $30 \mathrm{~mA}$ for $150 \mathrm{sec}$ and the picture was taken by SEM (Quanta ${ }^{\mathrm{m}} 250 \mathrm{FEG}$, FEI Company, Hillsboro, OR) at $12 \mathrm{kV}$.

\section{S rRNA and gyrase A (gyrA) gene polymerase chain reaction (PCR) and sequencing}

The genomic DNA of Bacillus sp. VJ-1 was isolated by using kit method. $16 \mathrm{~S}$ rRNA and gyrase A ( $g y r A)$ gene nucleotide sequences were amplified from chromosomal DNA by PCR using universal oligo-nucleotide primers, 27 forward primer (FP) (5' AGA GTT TGA TCG TGG CTC AG 3') and 1492 reverse primer (RP) (3' GGT TAC CTT GTT ACG ACT T 5') for (16S rDNA); $43 \mathrm{FP}$ (5' CAG TCA GGA AAT GCG TAC GTC CTT 3'), 1065 RP, (3' CAAGGTAATG CTCCAGGC ATTGCT 5') for $(g y r A)$. The sequences were then compared in the GenBank database. Multiple sequence alignment was done and phylogenetic tree was constructed by the neighbor-joining method using MEGA (Version 4.1) software. The confidence level of each branch (1000 repeats) was tested by bootstrap analysis. The $16 \mathrm{~S}$ rRNA sequences of $B$. amyloliquefaciens VJ-1was deposited in the GenBank database. 


\section{Fermentation}

\section{Preparation of seed culture}

To prepare the inoculum for fermentation experiments, two glycerol stock vials were used to inoculate $1000 \mathrm{ml}$ flask containing $350 \mathrm{ml} \mathrm{LB}$ medium. The seed activation culture was grown at the $37^{\circ} \mathrm{C}$ for $16 \mathrm{~h}$. Two generations of activation cultures were prepared before fermentation for transferring metabolically active cells. This culture was used as the seed culture.

\section{Batch fermentation of Bacillus sp. VJ-1 and extraction of metabolites}

Batch fermentation was performed in a $10 \mathrm{l}$ bioreactor (B-Braun). Seven liters of sterilized MNGA fermentation medium were added to the fermentor, and $350 \mathrm{ml}$ (5\%) seed culture was inoculated. Agitation was monitored at a low rate $(200 \mathrm{rpm})$ just sufficient to mix the $\mathrm{pH}$ control reagent into the medium. The fermentation temperature was adjusted to $37^{\circ} \mathrm{C}$, and the $\mathrm{pH}$ was adjusted to 7.0 with $2 \mathrm{~N} \mathrm{NaOH}$. At the end of the fermentation cycle the culture was filtered and the supernatant was separated by centrifuging at 12,000 rpm for $20 \mathrm{~min}$. The supernatant $\mathrm{pH}$ was adjusted to five by using $0.1 \mathrm{~N}$ $\mathrm{HCl}$ and then extracted with hexane, ethyl acetate and chloroform. The filtrates were concentrated under reduced pressure at $37^{\circ} \mathrm{C}$ and stored in a refrigerator at $4^{\circ} \mathrm{C}$ for subsequent antimicrobial screening. The percent yield of the extracts was $0.048,0.029$ and $0.067 \%(\mathrm{w} / \mathrm{v})$ respectively for hexane, ethyl acetate and chloroform. The crude extracts were recuperated in DMSO and evaluated antimicrobial activity.

\section{Fungal biomass inhibition effect of Bacillus sp. VJ-1}

Fungal biomass inhibition was examined by inoculating mid-log phase Bacillus sp. VJ-1into individual $250 \mathrm{ml}$ Erlenmeyer flask containing $100 \mathrm{ml}$ MNGA broth and cultivating them for $48 \mathrm{~h}$ at $37^{\circ} \mathrm{C}$ on an orbital incubator shaker. Cell-free supernatants were collected by centrifugation at $12,000 \mathrm{rpm}$ for $20 \mathrm{~min}$. Aliquots $(10 \mathrm{ml})$ of supernatant with $40 \mathrm{ml}$ of PD broth (potato $200 \mathrm{~g} \mathrm{l}^{-1}$, dextrose $20 \mathrm{~g} \mathrm{l}^{-1}$ ) were placed in $50 \mathrm{ml}$ flasks and inoculated in triplicate with each test fungus. The fungal strains were incubated at $30^{\circ} \mathrm{C}$ for 5 days. Flasks without fermentation broth were the positive control. The growth performance of all fungal strains was checked separately in PD broth containing $100 \mathrm{mM}$ acetic acid, lactic acid, ethanol and succinic acid to ensure that fungal inhibition was not simply due to nutrient exhaustion of the growth medium or acid production. After the incubation, fungal growth was measured by harvesting the cells, which were air-dried on preweighed Whatman \#1 filter paper. Average fungal biomass was calculated for each test fungus and compared with the fungal biomass of positive controls.

\section{Minimum inhibitory concentration against bacteria}

The minimum inhibitory concentrations (MIC) of extracts were tested against bacteria by broth micro dilution method [1]. The cell growth of the bacterial strains was adjusted to a McFarland standard 0.5 equivalent to concentrations of $1-5 \times 10^{8} \mathrm{cfu} / \mathrm{ml}$. The microbial suspensions were further diluted (1:100) in media to obtain a final inoculum of approximately $1.5 \times 10^{6} \mathrm{cfu} / \mathrm{ml}$. MIC was determined as the lowest concentration of the extracts inhibiting the visual growth of the test cultures. Three replicates were maintained to confirm the antifungal activity.

\section{Minimum inhibitory concentration against fungi}

The antifungal activity and minimum inhibitory concentration (MIC) was performed according to the standard reference method [8]. Crude extracts were dissolved in sterile water together with $2 \%$ di-methyl sulfoxide (DMSO). The initial test concentration was serially diluted twofold. Each well was inoculated with $5 \mu \mathrm{l}$ of suspension containing $10^{4}$ spore $\mathrm{ml}^{-1}$ of fungi. The antifungal agent ketoconazole was used as positive control. Plates were incubated 24,48 or $72 \mathrm{~h}$ at $28^{\circ} \mathrm{C}$. MIC was determined as the lowest concentration of the extracts inhibiting the visual growth of the test cultures. Three replications were maintained to confirm the antifungal activity.

\section{Microorganisms}

Bacteria: B. subtilis (ATCC 7972), Enterococcus cloacae (ATCC 29212), Staphylococcus aureus (ATCC 25923), S. epidermidis (MTCC 3615). Fungi: Aspergillus clavatus (KCTC 40071), A. fumigates (KCTC 40080), A. niger (KCTC 40280), A. oryzae (KCTC 44823), Curvularia lunata (KCTC 40392), Fusarium oxysporum (KCTC 40051), Gibberella moniliformis (KCTC 44022), Humicola grisea (KCTC 40860), Penicillium chrysogenum (KCTC 40399) and P. roqueforti (KCTC 41354) were used for the experiment.

\section{Probiotic properties of Bacillus sp. VJ-1 Tolerance to low $\mathrm{pH}$}

Tolerance to low $\mathrm{pH}$ was determined using the plate count method. Briefly, active Bacillus sp. VJ-1 was grown in LB broth and was inoculated (1\%) in $10 \mathrm{ml}$ of fresh LB broth adjusted to $\mathrm{pH} 3.0$ and 4.0 with hydrochloric acid $(1.0 \mathrm{~N})$ and incubated at $37^{\circ} \mathrm{C}$ for $3 \mathrm{~h}$. Samples were withdrawn at 0 and $3 \mathrm{~h}$ of incubation to measure the initial bacterial population and residual cell population by plating suitable dilutions on LB agar plates. The plates were incubated at $37^{\circ} \mathrm{C}$ for $24 \mathrm{~h}$, and the number of colonies that grew was counted. The experiment was performed in triplicate. 


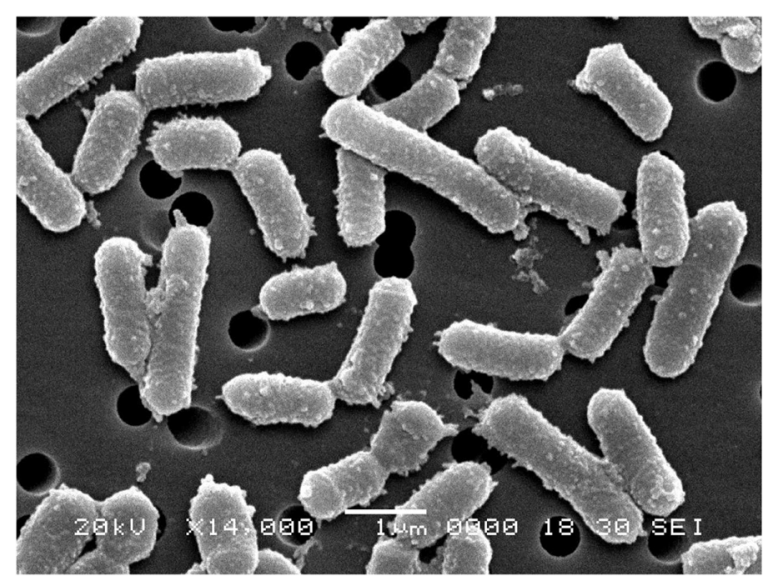

Figure 1 Scanning electron microscopic image of Bacillus amyloliquefaciens $\mathrm{VJ}-1$.

\section{Bile tolerance}

The ability of Bacillus sp. VJ-1 to grow in the presence of two different bile salts was studied according to the method of Vinderola and Reinheimer with slight modification [9]. LB-thiobroth (LB supplemented with $0.2 \%$ sodium thioglycollate) and LB-thiobroth supplemented with $0.3 \%(\mathrm{w} / \mathrm{v})$ Oxgall were freshly prepared and inoculated overnight with
1\% suspensions of Bacillus sp. VJ-1. Samples without Oxgall were considered the control. After $24 \mathrm{~h}$ incubation at $37^{\circ} \mathrm{C}$, bacterial concentration was checked by a viable count determination on LB agar by plating suitable dilutions. The experiment was performed in triplicate.

\section{Biogenic amine production}

Production of biogenic amines was assessed by the method described by Bover-Cid [10]. Briefly, a 0.5 optical density at $600_{\mathrm{nm}}\left(\mathrm{OD}_{600}\right)$ aliquot of freshly prepared Bacillus sp. VJ-1 cells were inoculated on LB agar medium supplemented with $1.0 \%$ each of lysine, tyrosine, ornithine, and histidine. Tween $80(0.1 \%)$ was included in the medium to enhance bacterial growth. Bromocresol purple $(0.006 \%)$ was used as the $\mathrm{pH}$ indicator. The formation of a clear purple halo was considered a positive reaction, indicating the presence of the respective amino acid decarboxylase. Medium without supplementing amino acids was considered the negative control, and the experiment was performed in triplicate.

\section{Proteolytic activity}

The proteolytic activity was measured by growing Bacillus sp. VJ-1 cells in $10 \%$ skim milk at $37^{\circ} \mathrm{C}$ for $42 \mathrm{~h}$. The absorbance was read at $650 \mathrm{~nm}$ with an ELISA reader (Bio-

Table 1 Biochemical and physiological characteristics of Bacillus amyloliquefaciens VJ-1

\begin{tabular}{|c|c|c|c|}
\hline \multirow[t]{2}{*}{ Substrates } & \multirow[t]{2}{*}{ Reactions/Enzyme } & \multicolumn{2}{|l|}{ Results $^{a}$} \\
\hline & & B. amyloliquefaciens VJ-1 & B. subtilis (ATCC 7972) \\
\hline ONPG & $\beta$-galactosidase & - & - \\
\hline Arginine & Arginine dihydrolase & - & - \\
\hline Lysine & Lysine decarboxylase & - & - \\
\hline Ornithine & Ornithine decarboxylase & + & + \\
\hline Sodium citrate & Citrate utilization & + & + \\
\hline Sodium thiosulfate & $\mathrm{H}_{2} \mathrm{~S}$ production & - & - \\
\hline Urea & Urease & - & - \\
\hline Tryptophane & Tryptophane deaminase & - & - \\
\hline Creatine sodium pyruvate & Acetoin production & - & - \\
\hline Kohn's gelatin & Gelatinase & + & + \\
\hline Glucose & Fermentation/oxidation & + & + \\
\hline Mannitol & Fermentation/oxidation & + & + \\
\hline Inositol & Fermentation/oxidation & + & + \\
\hline Sorbitol & Fermentation/oxidation & + & + \\
\hline Rhamnose & Fermentation/oxidation & + & + \\
\hline Sucrose & Fermentation/oxidation & + & + \\
\hline Melibiose & Fermentation/oxidation & - & - \\
\hline Amygdalin & Fermentation/oxidation & + & + \\
\hline Arabinose & Fermentation/oxidation & + & + \\
\hline
\end{tabular}

+: Positive (more than 90\%).

-: Negative (more than 90\%).

${ }^{a}$ The results were measured after incubating the strains for $24 \mathrm{~h}$ at $37^{\circ} \mathrm{C}$. 
Rad) [11]. The results were expressed as milligrams/milliliter tyrosine by means of reference to a calibration curve.

\section{Evaluation of cell surface hydrophobicity}

The cell surface hydrophobicity assay was conducted according to the method described by Lee et al. with slight modifications [12]. Briefly, freshly prepared cells were centrifuged at $8000 \mathrm{rpm}$ for $10 \mathrm{~min}$. The cells were washed twice with PBS (pH 7.0). One ml of this suspension was used to determine the absorbance at $\mathrm{OD}_{580} \mathrm{~nm}$. In duplicate assessments, a further $1 \mathrm{ml}$ of this suspension was added to an equal volume of $\mathrm{n}$-hexadecane (Sigma, USA) and was thoroughly mixed for 2 min using a vortex. The phases were allowed to separate at room temperature for $30 \mathrm{~min}$, after which $1 \mathrm{ml}$ of the upper phase was removed and the absorbance was determined at $\mathrm{OD}_{580} \mathrm{~nm}$. Percentage hydrophobicity was calculated as follows: $\left(\mathrm{OD}_{580} \mathrm{~nm}\right.$ reading $1-\mathrm{OD}_{580} \mathrm{~nm}$ reading $2 / \mathrm{OD}_{580} \mathrm{~nm}$ reading 1$) \times 100=\%$ hydrophobicity.

\section{In vitro antioxidant activity of Bacillus sp. VJ-1 cells} Resistance to hydrogen peroxide

The method of Buchmeier et al. was used with some modifications [13]. Briefly, $0.3 \mathrm{OD}_{600} \mathrm{~nm}$ of Bacillus sp.
VJ-1 cells were grown in $500 \mathrm{ml}$ Erlenmeyer flasks containing $100 \mathrm{ml} \mathrm{LB}$ broth supplemented with 0.2, 0.4, 0.6, 0.8 and $1.0 \mathrm{mM}$ hydrogen peroxide, at $37^{\circ} \mathrm{C}$ on an orbital incubator shaker. Cell growth was measured spectrophotometrically at $600_{\mathrm{nm}}$, and increase in cell growth were measured as increases in optical density (OD).

\section{Hydroxyl radical scavenging activity}

The hydroxyl radical scavenging assay was conducted by a Fenton reaction method [14]. Briefly, the reaction mixture containing $1.0 \mathrm{ml}$ of brilliant green $(0.435 \mathrm{mM})$, $2.0 \mathrm{ml}$ of $\mathrm{FeSO}_{4}(0.5 \mathrm{mM}), 1.5 \mathrm{ml}$ of $\mathrm{H}_{2} \mathrm{O}_{2}(3.0 \%$, w/v), and 1.0, 1.5, 2.0 and $2.5 \mathrm{ml}$ of freshly prepared Bacillus sp. VJ-1 cells cells $\left(10^{9} \mathrm{CFU} / \mathrm{ml}\right)$ was incubated at room temperature for $15 \mathrm{~min}$, and the absorbance was then measured at $624_{\mathrm{nm}}$. The change in absorbance of the reaction mixture indicated the scavenging ability of the $B$. amyloliquefaciens VJ-1 cells for hydroxyl radicals.

$$
\begin{aligned}
\text { Scavenging activity }(\%)= & {\left[\left(A_{s}-A_{0}\right) /\left(A-A_{0}\right)\right] } \\
\times & 100
\end{aligned}
$$

Where $A \mathrm{~s}$ is the absorbance in the presence of the sample, $A_{0}$ is the absorbance of the control in the

Table 2 Comparative antibiotic sensitivity pattern of Bacillus amyloliquefaciens VJ-1 towards various antibiotics

\begin{tabular}{|c|c|c|c|}
\hline Antibiotic group & Antimicrobial agent & Disc potency $(\mu \mathrm{g})$ & Diameter of inhibition zone $(\mathrm{mm})^{\mathrm{a}}$ \\
\hline \multirow[t]{5}{*}{ Aminoglycoside } & Amikacin & 30 & 22 \\
\hline & Gentamicin & 10 & 0 \\
\hline & Kanamycin & 30 & 0 \\
\hline & Streptomycin & 10 & 11 \\
\hline & Tobramycin & 10 & 25 \\
\hline Carboxypenicillin & Carbenicillin & 50 & 27 \\
\hline \multirow[t]{4}{*}{$\beta$-lactamase inhibitor } & Ampicillin & 50 & 29 \\
\hline & Augmentin & 30 & 25 \\
\hline & Imipenem & 10 & 30 \\
\hline & Ticarcillin & 75 & 31 \\
\hline \multirow[t]{8}{*}{ Fluroquinolone } & Ciprofloxacin & 5 & 17 \\
\hline & Gatifloxacin & 5 & 15 \\
\hline & Levofloxacin & 5 & 20 \\
\hline & Moxifloxacin & 5 & 20 \\
\hline & Nalidixic acid & 30 & 22 \\
\hline & Norfloxacin & 10 & 26 \\
\hline & Ofloxacin & 5 & 26 \\
\hline & Sparfloxacin & 5 & 28 \\
\hline \multirow[t]{2}{*}{ Cephalosporin } & Cefpodoxime & 10 & 22 \\
\hline & Cetriaxone & 30 & 25 \\
\hline Polymixin & Colistin & 10 & 19 \\
\hline Sulphonamide & Co-Trimoxazole & 25 & 18 \\
\hline
\end{tabular}

Zones of inhibition were measured after incubating the strains for $17 \mathrm{~h}$ at $37^{\circ} \mathrm{C}$ in $\mathrm{LB}$ agar medium. 


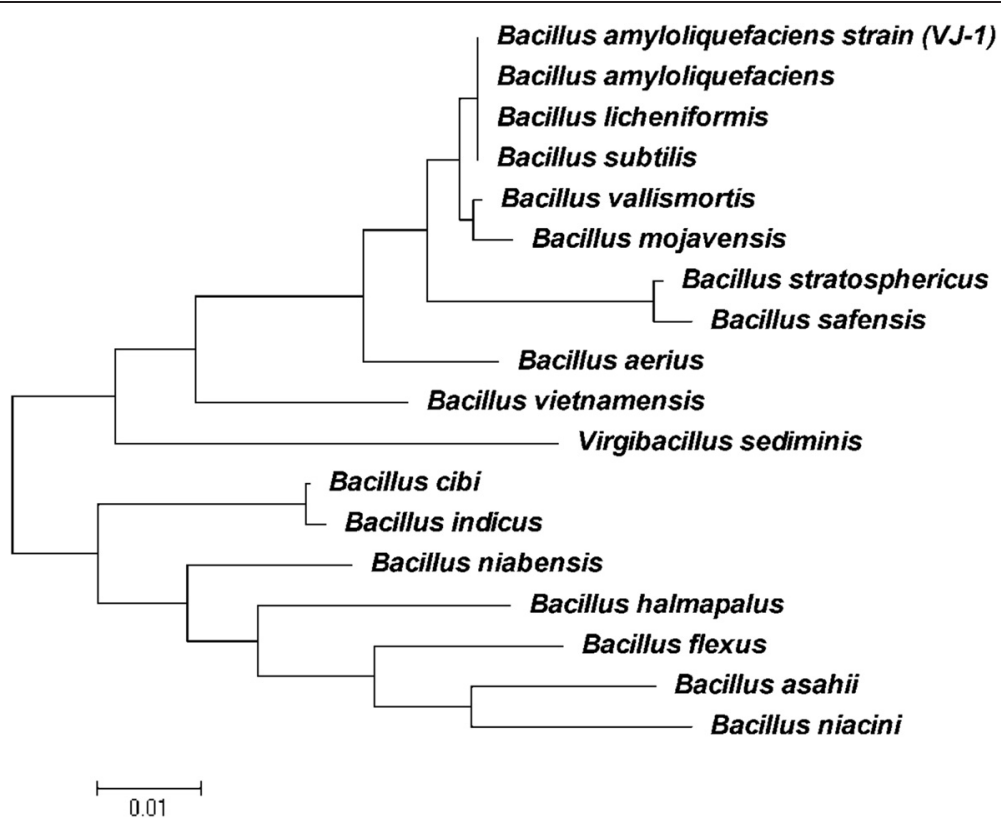

Figure 2 Phylogenetic tree based on 16S rDNA gene sequence showing the relationship between VJ-1 strains and species belonging to the genus Bacillus. The tree was constructed using the neighbor-joining method.

absence of the sample, and A is the absorbance without the sample and Fenton reaction system.

\section{DPPH free radical scavenging activity}

The DPPH radical-scavenging capacity was determined according to the method described by Li et al. with some modifications [15]. Briefly, 1.0, 1.5, 2.0 and $2.5 \mathrm{ml}$ of freshly prepared Bacillus sp. VJ-1 cells $\left(10^{9} \mathrm{CFU} / \mathrm{ml}\right)$, was added to $1.0 \mathrm{ml}$ methanolic DPPH radical solution $(0.05 \mathrm{mM})$. The mixture was mixed vigorously and incubated at room temperature in the dark for $30 \mathrm{~min}$. The controls included only deionized water and DPPH solution. The blanks contained only methanol and the cells. The absorbance of the resulting solution was measured in triplicate at $517_{\mathrm{nm}}$, after centrifugation at $12000 \mathrm{rpm}$ for $10 \mathrm{~min}$.

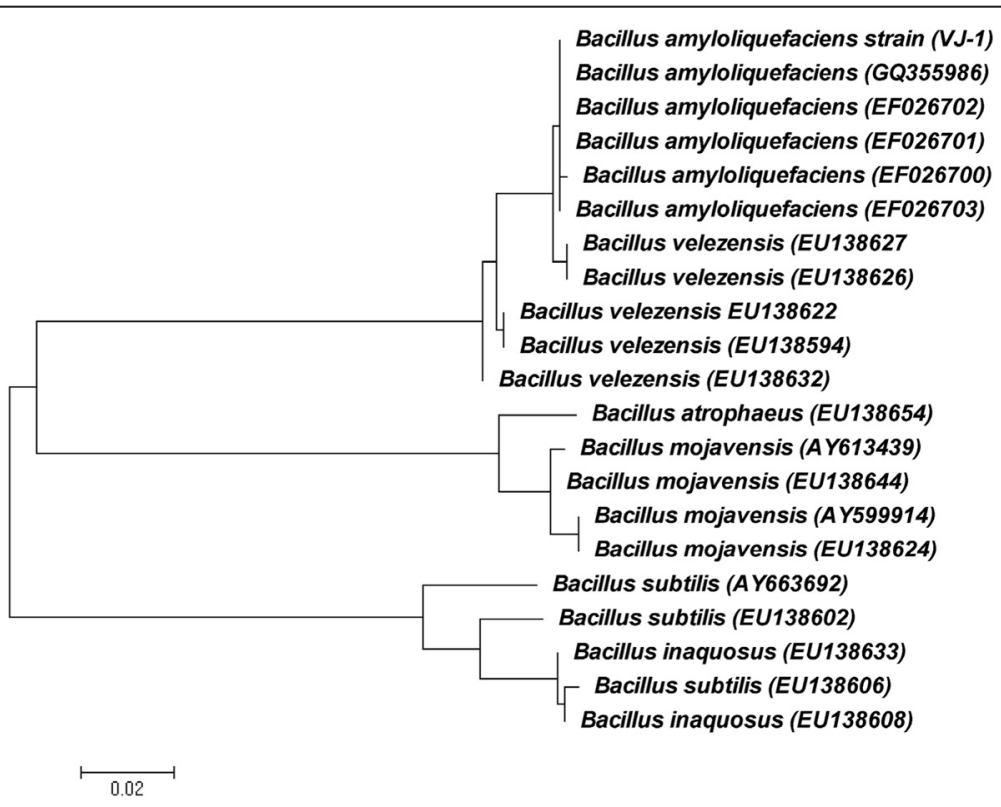

Figure 3 Phylogenetic tree based on gyrase A gene sequence showing the relationship between VJ-1 strains and species belonging to the genus Bacillus. The tree was constructed using the neighbor-joining method. 


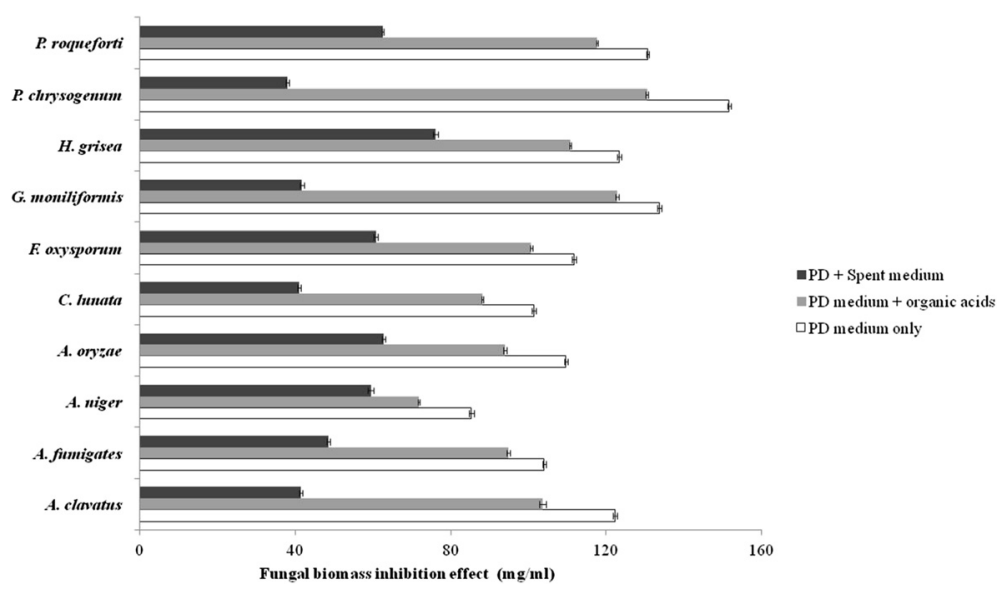

Figure 4 Fungal biomass inhibition effect of Bacillus amyloliquefaciens VJ-1. The fungal biomass inhibition effect of Bacillus amyloliquefaciens VJ-1 fermentation medium was evaluated by mixing with PD medium.

Scavenging activity $(\%)=\underset{\times 100}{\left[1-\left(A_{\text {sample }}-A_{\text {blank }}\right) / A_{\text {control }}\right]}$

\section{Results and discussion}

Isolation and identification of strain

In the present study, 20 different strains were isolated from the silage samples, among which one strain named VJ-1 exhibited good antimicrobial activity against Gram positive and filamentous fungi were selected. The strain was observed as Gram-positive, aerobic, motile, rodshaped (0.6-0.9 $\mu \mathrm{m}$ width and 1.9-3.10 $\mu \mathrm{m}$ length), and the SEM picture was shown in Figure 1. The morphology of the strain was tiny, opaque and cells were rough, leathery on the surface of the agar plates. Physiological and biochemical characters were firstly used to identify the strain after that subjected to identification by API system. The biochemical characters of the strain VJ-1 was showed in Table 1. Except for gentamicin (10 $\mu \mathrm{g}$ per disc), kanamycin $(30 \mu \mathrm{g}$ per disc), all the antibiotics tested in this study inhibited the growth of VJ-1 to some extent (Table 2). $\beta$-lactamase inhibiter group antibiotics ampicillin and imipenem showed the highest zone of inhibition $29 \mathrm{~mm}$ and $30 \mathrm{~mm}$ respectively. Most of the tested antibiotic disc documented above $20 \mathrm{~mm}$ as zone of inhibition. The results of biochemical and physiological characteristics revealed similar percentage of identity with $B$. subtilis. The percentage identity is to estimate of how closely the profile of the strain corresponds to the taxon relative to all other microorganisms. To confirm the strain, further identification was performed using 16S rRNA and gyrA gene amplification and sequencing. The $16 \mathrm{~S}$ rRNA sequence of the strain showed that $>99 \%$ similarity of alignment to B. subtilis, $B$. licheniformis, B. vallismortis, B. velezensis, B. mojavensis and $B$. amyloliquefaciens (Figure 2). These species are considered as members of the $B$. subtilis group and their similarity on the basis of $16 \mathrm{~S}$ rRNA sequence has been discussed [16]. However, 16S rRNA gene sequences showed limited variation in the closely related species of B. subtilis group (e.g. B. subtilis and B. amyloliquefaciens showed more than $99 \%$ similarities) and prevents the resolution of strain and species relationship [17]. Chun and Bae, reported that the sequence analysis of the gyr A sequence could accurately confirm $B$. subtilis and related taxa [16]. Gyrase $A$ nucleotide sequences were analyzed by NCBI BLAST program showed the closest similarity relative to $B$. amyloliquefaciens, with sequence similarity of $99 \%$ (Figure 3). It is considered that, if the sequence identity showed above $99 \%$ similarity we could definitely

Table 3 Antibacterial activities of organic extracts obtained from Bacillus amyloliquefaciens VJ-1

\begin{tabular}{|c|c|c|c|c|c|c|}
\hline \multirow[t]{2}{*}{ Indicator bacteria } & \multirow{2}{*}{$\begin{array}{l}\text { Inhibitory } \\
\text { activity (mm) }\end{array}$} & \multicolumn{5}{|c|}{ Minimum inhibitory concentration $(\mu \mathrm{g} / \mathrm{ml})$} \\
\hline & & $\mathrm{HE}$ & EA & CE & C & S-1 \\
\hline Bacillus subtilis (ATCC 7972) & $20.16 \pm 0.28$ & 75.00 & 25.00 & 125.00 & 12.50 & 7.50 \\
\hline Enterococcus cloacae (ATCC 29212) & $19.00 \pm 0.5$ & 75.00 & 25.00 & 125.00 & 12.50 & 6.25 \\
\hline Staphylococcus aureus (ATCC 25923) & $22.33 \pm 0.57$ & 50.00 & 25.00 & 100.00 & 25.00 & 6.25 \\
\hline Staphylococcus epidermidis (MTCC 3615) & $29.83 \pm 0.76$ & 100.00 & 12.50 & 100.00 & 31.50 & 3.75 \\
\hline
\end{tabular}

HE: (Hexane extract), EE: (Ethyl acetate extract), CE: (Chloroform extract), S (Streptomycin), fungal control reference. Values are means of triplicate. ${ }^{\mathrm{a}}$ The antibacterial activity were monitored by growing the bacteria in $\mathrm{MH}$ and incubated at $37^{\circ} \mathrm{C}$ for $17 \mathrm{~h}$. 
Table 4 Antifungal activities of organic extracts obtained from Bacillus amyloliquefaciens VJ-1

\begin{tabular}{lllll}
\hline Indicator fungi & \multicolumn{1}{l}{ Minimum inhibitory concentration $\mathbf{( m g / m L}$} & & \\
\cline { 2 - 5 } & HE & EA & 100.00 & S-1 \\
\hline Aspergillus clavatus & 50.00 & 25.00 & 100.00 & 12.50 \\
Aspergillus fumigates & 50.00 & 25.00 & 100.00 & 25.00 \\
Aspergillus niger & 37.50 & 25.00 & $>100$ & 12.50 \\
Aspergillus oryzae & 25.00 & 50.00 & $>75$ & 50.00 \\
Curvularia lunata & 50.00 & 50.00 & 100.00 & 25.00 \\
Fusarium oxysporum & 25.00 & 37.50 & 100.00 & 12.50 \\
Gibberella moniliformis & $>100$ & 25.00 & $>100$ & 25.00 \\
Humicola grisea & $>100$ & 100.00 & $>100$ & 37.50 \\
Penicillium chrysogenum & $>100$ & 100.00 & $>100$ & 37.50 \\
Penicillium roqueforti & $>100$ & 100.00 & 50.00 \\
\hline
\end{tabular}

HE: (Hexane extract), EE: (Ethylacetate extract), CE: (Chloroform extract), S (Ketoconazole), fungal control reference. Values are means of triplicate. The antifungal activity were monitored by growing the fungi in PD medium and incubated at $30^{\circ} \mathrm{C}$ for $28 \mathrm{~h}$.

conclude that the two strains belong to the same species, and if the identity is higher than $97 \%$, strains are classified in the same genus or the same family. Therefore on the basis of morphological, physiological, biochemical characteristics, phylogenetic position and gene sequences of $16 \mathrm{~S}$ rRNA and gyrA, the isolated strain was confirmed as $B$. amyloliquefaciens.

\section{Fungal biomass inhibition effect}

After three day incubation, VJ-1 significantly inhibited the growth of fungi, compared with that of LB controls and LB medium with lactic acid, acetic acid, succinic acid and ethanol based on dry weight measurements of fungal biomass (Figure 4). The greatest antifungal growth inhibitory activity of VJ-1 was recorded against $P$. chrysogenum (75.02\%), followed by G. moniliformis (68.84\%), A. clavatus (66.18\%), C. lunata (59.56\%) and A. fumigates (53.33\%). The test fungi were not inhibited by the mixture of organic acids, suggesting that the fungal inhibition seen in the VJ-1 cell-free culture was due to the presence of other inhibitory compounds.

\section{Antibacterial activity}

The antibacterial activities of the extracts were determined in terms of MIC (Table 3). Ethyl acetate and hexane extracts obtained from the isolates showed significant antimicrobial activity against Gram positive bacterial pathogens. Hexane extract exhibited MIC $50 \mu \mathrm{g} / \mathrm{ml}$ for $S$. aureus. It exhibited MIC value $75 \mu \mathrm{g} / \mathrm{ml}$ for B. subtilis and E. cloacae respectively. Whereas, $S$. epidermidis documented MIC value $100 \mu \mathrm{g} / \mathrm{ml}$. The MIC values of the ethyl acetate extract are slightly similar or lesser than the standard broad spectrum antibiotic, streptomycin. The chloroform extract showed the highest MIC values. B. amyloliquefaciens GA1 produces cyclic peptides iturin A, surfactin and fengycin, and the ironsiderophore bacillibactin [18]. Iturin A was known for its antimicrobial activity. Marinomycin A isolated from Marinispora which inhibited the growth of human pathogenic bacteria such as methicillin-resistant $S$. aureus and vancomycin-resistant E. faecium [19].

\section{Antifungal activity}

Hexane, ethyl acetate and chloroform extracts were screened against fungi. Minimum inhibitory concentration

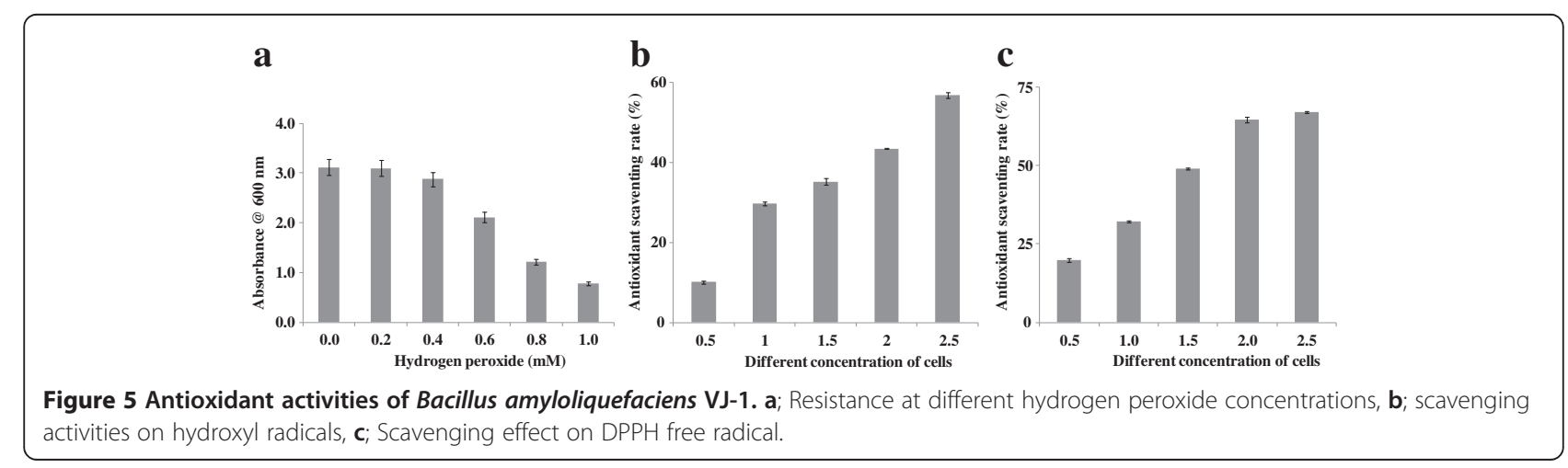


Table 5 Cell viability of Bacillus amyloliquefaciens VJ-1 under low pH

\begin{tabular}{lllllll}
\hline $\mathbf{p H}$ & $\mathbf{0} \min$ & $\mathbf{3 0} \mathbf{m i n}$ & $\mathbf{6 0} \mathbf{m i n}$ & $\mathbf{9 0} \mathbf{m i n}$ & $\mathbf{1 2 0} \mathbf{m i n}$ & $\mathbf{1 5 0} \mathbf{m i n}$ \\
\hline 3.0 & $8.46 \pm 0.015$ & $8.40 \pm 0.010$ & $8.53 \pm 0.020$ & $8.61 \pm 0.037$ & $8.71 \pm 0.030$ & $8.79 \pm 0.026$ \\
4.0 & $8.48 \pm 0.020$ & $8.42 \pm 0.026$ & $8.61 \pm 0.010$ & $8.66 \pm 0.264$ & $8.76 \pm 0.017$ & $8.93 \pm 0.025$ \\
\hline
\end{tabular}

Values are means of triplicate determinations with standard deviations.

values are reported in Table 4. All the fungi exhibited marked antagonistic activity against the extracts (ethyl acetate extract showed comparatively better activity than hexane and chloroform extracts). Ethyl acetate extracts exhibited MIC $2.5 \mathrm{mg} / \mathrm{ml}$ for A. clavatus, A. fumigates, A. niger and G. moniliformis. A. oryzae and C.lunata showed good activity $5.0 \mathrm{mg} / \mathrm{ml}$. Overall the isolated extracts inhibited the growth of fungi higher to the standard antibiotic ketoconazole. There have already been many reports about the antifungal activities of metabolites isolated from the natural sources against $C$. albicans, Cryptococcus neoformans, $T$. mentagrophytes and A. fumigates [20]. The activity could be due to alteration in the cell membrane permeability [21]. It is known that some B. amyloliquefaciens strains could produce surfactin, iturin and fengycin production [22]. Iturins are a group of antifungal, cyclic lipopeptodes, consisting of iturin A-E, bacillomycin $\mathrm{D}, \mathrm{F}$ and $\mathrm{L}$, and mycosubtilin. There are several reports on antifungal activity of novel metabolites produced by microorganisms. Lavermicocca et al. reported that 3-phenyllactic acid produced by some strains of Bacillus exhibited growth inhibitory effects against a wide range of mould species, which includes Aspergillus ochraceus, Penicillium roqueforti, P. citrinu [23]. Sjogren et al. showed that 3-hydroxy fatty acids from Bacillus revealed significant antifungal activity against different molds and yeasts [24]. Pseudomonas sp. was known to produce phenazine-1-carboxylic acid, another antifungal secondary metabolite [25].

\section{Antioxidant activity}

\section{Resistance to hydrogen peroxide}

The effect of hydrogen peroxide on the viability of the strain VJ-1 is shown in Figure 5(a). 4. Results revealed that the strain could able to tolerate $0.8 \mathrm{mM} \mathrm{H}_{2} \mathrm{O}_{2}$, whereas at $1.0 \mathrm{mM}$ concentration the growth was slightly reduced with optical densities 0.76 after incubation for $8 \mathrm{~h}$.

\section{Hydroxyl radical scavenging activity}

The results for hydroxyl scavenging assay of the strain VJ-1 are shown in Figure 5b. The hydroxyl radical scavenging activity was increased with increasing quantity concentration the cells. The hydroxyl radical scavenging ability of the strain indirectly proportional to the concentration of the cells. The result revealed that the strain had the highest hydroxyl radical scavenging ability with an inhibition rate of $56.84 \%$ at $2.5 \mathrm{ml}$ of cells at $10^{8} \mathrm{CFU} / \mathrm{ml}$.

\section{DPPH free radical scavenging activity}

The methanol extract of the strain VJ-1 exhibited a significant dose dependent inhibition of DPPH activity, with the highest radical-scavenging activity (67.33\%) at $2.5 \mathrm{ml}$ of cells at $10^{8} \mathrm{CFU} / \mathrm{ml}$. The results are presented in Figure 5c.

\section{Probiotic properties}

The ability of microorganisms to survive in the gastrointestinal tract condition is one of the main important characteristics required for probiotic bacteria. Therefore, the viability at low $\mathrm{pH}$ and bile salt conditions were studied. The viability of the VJ-1 at $\mathrm{pH} 3.0$ and 4.0 are presented in Table 5. The result indicated that the cell viability was slightly increased at $\mathrm{pH}$ 3.0. Whereas, at $\mathrm{pH} 4.0$ the strain withstands and grown. The survival ability of the strain in the presence of bile salts (Oxgall $(0.3 \%)$ and sodium taurocholate $(0.3 \%))$ is presented in Table 6 . The results revealed that the strain was able to grow in the presence of sodium taurocholate and was highly sensitive to oxgall. Proteolytic activity was determined as $0.051 \mathrm{mg} / \mathrm{ml}$ tyrosine liberation. A positive result for decarboxylase activity with tyrosine was observed, and exhibited high hydrophobicity (100\%). Therefore strain VJ-1 is considered as safe in usage as probiotics as reported by the researchers [26-28].

It has been suggested that probiotics play various biological roles through several mechanisms, one of the most debated being the antioxidant activity [29]. The antioxidant supplementation helps in reducing the level of oxidative stress and in slowing or preventing the development of complications associated with diseases [30]. It is

Table 6 Cell viability of Bacillus amyloliquefaciens VJ-1 under bile salt condition

\begin{tabular}{lllll}
\hline Sample & $\mathbf{0} \mathbf{m i n}$ & $\mathbf{6 0} \mathbf{~ m i n}$ & $\mathbf{1 2 0} \mathbf{~ m i n}$ & $\mathbf{1 8 0} \mathbf{~ m i n}$ \\
\hline Control & $8.55 \pm 0.37$ & $8.65 \pm 0.43$ & $8.9 \pm 0.08$ & $9.08 \pm 0.19$ \\
MRS+Na.Taurocholate & $8.84 \pm 0.04$ & $8.61 \pm 0.01$ & $8.83 \pm 0.03$ & $8.94 \pm 0.04$ \\
MRS+Na.Taurocholate+Oxgall & $8.42 \pm 0.02$ & $8.17 \pm 0.03$ & $8.06 \pm 0.04$ & \\
\hline
\end{tabular}

Values are means of triplicate determinations with standard deviations. 
reported that few probiotic strains such as Streptococcus thermophilus, Bifidobacterium longum, L. plantarum and L. casei possesses strong antioxidative activity, and are able to decrease the risk of accumulation of ROS during the ingestion of food [31]. The beneficial effects of probiotic strains with oxidative stress were reported by several authors [32-36]. DPPH free radical scavenging study indicated that the cell surface active compounds of strain VJ-1 may involved in the antioxidant activity and it is directly proportional to the cell concentration. The reason for the activity may because of the existence of enzymes, such as NADH-oxidase, SOD, NADH peroxide, and non-haem catalases respectively.

\section{Conclusions}

From the present study, it is clear that a novel B. amyloliquefaciens VJ-1 produced extracellular product effective against bacteria and fungi. VI-1 displayed significant biological activity against Gram positive bacterial pathogens and filamentous fungal pathogens. It contained good functional probiotic properties, such as high tolerance to low $\mathrm{pH}$ and bile salts. The strain exhibited strong hydrogen peroxide resistant ability, hydroxyl radical and DPPH free radical scavenging activity. Therefore, it is confirmed that this B. amyloliquefaciens VJ-1 strain possesses several suitable characteristics which make it appropriate for use with various probiotic products.

\section{Competing interests}

The authors declare that they have no competing interests.

\section{Authors' contributions}

SK and TSR performed the experiments. SK, TSR drafted and wrote the manuscript. All authors read and approved the final manuscript.

\section{Acknowledgements}

The authors extend their appreciation to the Deanship of Scientific Research at King Saud University for funding the work through the research group project No. (RGP-VPP-073).

\section{Author details}

'Department of Botany and Microbiology, College of Science, King Saud University, Post box 2455, Riyadh 11451, Saudi Arabia. ${ }^{2}$ Department of Botany and Biotechnology, AJ College of Science and Technology, Thonnakal, Trivandrum, India. ${ }^{3}$ Department of Pharmacognosy and Medicinal, Aromatic \& Poisonous Plants Research Center (MAPPRC), College of Pharmacy, King Saud University, PO Box 2457, Riyadh 11451, Saudi Arabia.

Received: 27 October 2014 Accepted: 28 January 2015

Published online: 22 February 2015

\section{References}

1. Arasu MV, Duraipandiyan V, Ignacimuthu S. Antibacterial and antifungal activities of polyketide metabolite from marine Streptomyces sp. AP-123 and its cytotoxic effect. Chemosphere. 2013;90:479-87.

2. Huang X, Gao X, Zheng L, Hao G. Optimization of sterilization of Salmonella enteritidis in meat by surfactin and iturin using a response surface method. Int J Pept Res Ther. 2009;15:61-7.

3. Stein T. Bacillus subtilis antibiotics: structures, synthesis and specific functions. Mol Microbiol. 2005;56:845-57.

4. Sirtori LR, Motta AS, Brandelli A. Mode of action of antimicrobial peptide P45 on Listeria monocytogenes. J Basic Microbiol. 2008;48:393-400.
5. Romero DA, Vicente RH, Rakotoaly SE, Dufour JW, Veening E, Arrebola FM, et al. The iturin and fengycin families of lipopeptides are key factors in antagonism of Bacillus subtilis toward Podosphaera fusca. Mol Plant-Microbe Inter. 2007:20:430-40.

6. Arrebola E, Jacobs R, Korsten L. Iturin A is the principal inhibitor in the biocontrol activity of Bacillus amyloliquefaciens PPCB004 against postharvest fungal pathogens. J Appl Microbiol. 2010;108:386-95.

7. Kim PI, Ryu J, Kim YH, Chl YT. Production of bio-surfactant lipopeptides iturin $A$, fengycin, and surfactin A from Bacillus subtilis CMB32 for control of colletotrichum gloeosporioides. J Microbiol Biotech. 2010;20:138-45.

8. Rejiniemon TS, Arasu MV, Duraipandiyan V, Ponmurugan K, Al-Dhabi NA, Arokiyaraj S, et al. In-vitro antimicrobial, antibiofilm, cytotoxic, antifeedant and larvicidal properties of novel quinone isolated from Aegle marmelos (Linn.) Correa. Ann Clin Microbiol Antimicrob. 2014;13:48.

9. Vinderola CG, Reinheimer JA. Lactic acid starter and probiotic bacteria: a comparative in vitro study of probiotic characteristics and biological barrie resistance. Food Res Inter. 2003:36:895-904.

10. Bover-Cid S, Holzapfel WH. Improved screening procedure for biogenic amine production by lactic acid bacteria. Int J Food Microbiol. 1999;53(1):33-41.

11. Citi JE, Sandime WE, Eliker PR. Some observation on the Hull method for measurement of proteolysis in milk. J Dairy Sci. 1963;46:337-45.

12. Lee $\mathrm{H}$, Yoon H, Ji Y, Kim H, Park H, Lee J, et al. Functional properties of Lactobacillus strains isolated from kimchi. Int J Food Microbiol. 2011;145:155-61.

13. Buchmeier N, Bossie S, Chen CY, Fang FC, Guiney DG, Libby SJ. SlyA, a transcriptional regulator of Salmonella typhimurium, is required for resistance to oxidative stress and is expressed in the intracellular environment of macrophages. Infect Immun. 1997;65:3725-30.

14. He ZS, Luo H, Cao CH, Cui ZW. Photometric determination of hydroxyl free radical in Fenton system by brilliant green. Am J Chinese Clin Med. 2004:6:236-7.

15. Li S, Zhao Y, Zhang L, Zhang X, Huang L, Li D, et al. Antioxidant activity of Lactobacillus plantarum strains isolated from traditional Chinese fermented foods. Food Chem. 2012;135:1914-9.

16. Chun J, Bae KS. Phylogenetic analysis of Bacillus subtilis and related taxa based on partial gyrA gene sequences. Antonie Van Leeuwenhoek Inter J Gen Mol Microbiol. 2000;78:123-7.

17. Hutsebaut D, Vandroemme J, Heyrman J, Dawyndt P, Vandenabeele $P$, Moens $L$, et al. Raman microspectroscopy as an identification tool within the phylogenetically homogeneous 'Bacillus subtilis'-group. Syst Appl Microbiol. 2006:29:650-60.

18. Arguelles-Arias A, Ongena M, Halimi B, Lara Y, Brans A, Joris B, et al. Bacillus amyloliquefaciens GA1 as a source of potent antibiotics and other secondary metabolites for biocontrol of plant pathogens. Microb Cell Fact. 2009;8:63.

19. Kwon HC, Kauffman CA, Jensen PR, Fenical W. Marinomycins A-D antitumor antibiotics of a new structure class from a marine actinomycete of the recently discovered genus "Marinispora". J Am Chem Society. 2006;128:1622-32.

20. Agarwal SK, Singh SS, Verma S, Kumar S. Antifungal activity of anthraquinone derivatives from Rheum emodi. J Ethnopharma. 2000;72:43-6.

21. Haraguchi H, Kataoka S, Okamoto S, Hanafi M, Shibata K. Antimicrobia triterpenes from llex integra and the mechanism of antifungal action. Phytother Res. 1999:13:151-6.

22. Athukorala SNP, Fernando WGD, Rashid KY. Identification of antifungal antibiotics of Bacillus species isolated from different microhabitats using polymerase chain reaction and MALDI-TOF mass spectrometry. Can J Microbiol. 2009;55:1021-32.

23. Lavermicocca P, Valerio F, Visconti A. Antifungal activity of phenyllactic acid against molds isolated from bakery products. Appl Environ Microbiol. 2003:69:634-40.

24. Sjogren J, Magnusson J, Broberg A, Schnurer J, Kenne L. Antifungal 3- hydroxy fatty acids from Lactobacillus plantarum MiLAB 14. Appl Environ Microbiol. 2003;69(12):7554-7.

25. Thomashow LS, Weller DM, Bonsall RF, Pierson LS. Production of the antibiotic phenazine-1-carboxylic acid by fluorescent Pseudomonas species in the rhizosphere of wheat. Appl Environ Microbiol. 1990;56:908-12

26. Arasu MV, Jung M-W, Kim DH, llavenil S, Jane M, Park HS, et al. Enhancing nutritional quality of silage by fermentation with Lactobacillus plantarum. Ind J Microbiol. 2014;54(4):396-402.

27. Arasu MV, Jung MW, llavenil S, Kim DH, Park HS, Park JW, et al. Characterization, phylogenetic affiliation and probiotic properties of high 
cell density Lactobacillus strains recovered from silage. J Sci Food Agri. 2014:94(12):2429-40.

28. Arasu MV, Jung MW, Kim DH, Ilavenil S, Lee KD, Choi GJ, et al. Isolation and characterization of Lactobacillus plantarum KCC-19 from crimson silage. J Pure Appl Microbiol. 2014;8(8):3575-87.

29. Rossi M, Amaretti A. Probiotic properties of bifidobacteria. In: Mayo B, van Sinderen D, editors. Bifidobacteria: genomics and molecular aspects. UK: Horizon Scientific Press; 2010. p. 97-123. ISBN: 978-1-904455-68-4.

30. Kaizu H, Sasaki M, Nakajima $H$, Suzuki Y. Effect of antioxidative lactic acid bacteria on rats fed a diet deficient in vitamin E. J Dairy Sci. 1993;76:2493-9.

31. Lin MY, Yen CL. Antioxidative ability of lactic acid bacteria. J Agric Food Chem. 1999;47:1460-6.

32. Naruszewicz M, Johansson ML, Zapolska-Downar D, Bukowska H. Effect of Lactobacillus plantarum 299v on cardiovascular disease risk factors in smokers. Am J Clin Nutr. 2002;76:1249-55.

33. Songisepp E, Kals J, Kullisaar T, Mändar R, Hütt P, Zilmer M, et al. Evaluation of the functional efficacy of an antioxidative probiotic in healthy volunteers. Nutr J. 2005:4:22

34. Virtanen T, Pihlanto A, Akkanen S, Korhonen $\mathrm{H}$. Development of antioxidant activity in milk whey during fermentation with lactic acid bacteria. J Appl Microbiol. 2007;102:106-15.

35. Arasu MV, Al-Dhabi NA, Rejiniemon TS, Lee KD, Huxley VAJ, Kim DH, et al. Identification and characterization of Lactobacillus brevis P68 with antifungal, antioxidant and probiotic functional properties. Ind J Microbiol. 2015;55(1):19-28

36. Arasu MV, Kim DH, Kim PI, Jung MW, llavenil S, Jane M, et al. In vitro antifungal, probiotic and antioxidant properties of novel Lactobacillus plantarum K46 isolated from fermented sesame leaf. Ann Microbiol. 2013;64(3):1333-46.

\section{Submit your next manuscript to BioMed Central and take full advantage of:}

- Convenient online submission

- Thorough peer review

- No space constraints or color figure charges

- Immediate publication on acceptance

- Inclusion in PubMed, CAS, Scopus and Google Scholar

- Research which is freely available for redistribution 